\title{
Om ikke at ville være til uden at kunne fordi litteratur
}

\author{
BENT NYLANDER RASMUSSEN
}

Ikke blot handler "Time out" om tid, angst, bevidsthed og væren, disse er dens tema og motiv, hvad den behandler. For fortolkeren fremtræder denne omstændighed delvist som et problem, eftersom han, uanset om han er udsagns- eller udsigelsesfortolker, baserer sin fremfærd på en sondring mellem siges og menes, hvor fortolkningens opgave traditionelt er at oversætte det første til det sidste via analysens skille-ad-og-samle-igen. Fortolkerens problem med nærværende topografi er, at afstanden mellem siges og menes bevidst er elimineret, teksten reflekterer direkte på de abstrakter, som det ellers er fortolkningens ret at opløse teksten i. Den er for så vidt kommet sin fortolkning i forkøbet, for som alle minimalistiske skriftøvelser har også "Time out" en modvilje mod at blive fortolket, den vil hellere tages på ordet end at få oversat sin diskurs til en anden. Det ville altså være umiddelbart nytteløst at udtale sig om, hvorledes Bjelke forholder sig til verden uden for teksten; hvad der er at sige om eksistentialet, har jeg'et i sommerhuset allerede sagt. Vi må derfor acceptere en vis hermetisme, med mindre selvfølgelig vi læser topografien som et filosofisk skrift og som sådan går ind på argumentet. Hvis vi derimod fastholder, at vi har at gøre med en litterær tekst, hvilket en filosofisk analyse også hurtigt ville kunne fortælle os, får vi mulighed for at undersøge, hvad en tekst må være, der på samme tid skriver sig litterært og har den fortolkendes abstraktion som motiv, de to positioner er nemlig ikke umiddelbart forenelige. I bedste fald gives vi indblik i noget af det litteræres fænomenologi, eller knapt så fordringsfuldt: hvilke rekvisitter, sproglige som materielle, benytter den litterære tekst sig af, når 
den har abstrakter og kun sådanne i synsfeltet og hvordan ser bevidsthed og væren ud på et fotografi?

Hvis disse er spørgsmålene, svarer „Time out“ bl.a. følgende: For det første repræsenterer sommerhuset et mentalt rum, som til forskel fra byens sociabilitet befordrer en tilstand af absolut og næsten sublim væren. I sommerhusets afsondrethed kan jeg'et ubesværet reducere den mængde af effekter, som bevidstheden normalt henter sin logicitet og diskursivitet i. Opmærksomheden rettes mod eksistensen som sådan og mod værensrammerne i sig selv, primært bevidstheden, sekundært tid, drøm, angst, fordi disse ikke længere optræder i forhold til en hensigtsmæssighed, tiden går i stå eller bliver til evighed, og bevidstheden forsvinder allerede tyve linier inde i topografien, „Ingen forskel mellem bevidst og ubevidst, og derfor findes ingen bevidsthed." Her slutter "Time out", for allerede her er teksten nået til den indsigt, sọm på de følgende elleve sider eller så blot akkumulerer eksempler, nemlig den at alt nedskrives mod forskelsløshed, intethed, nul. Sommerhusgæsten forsøger til dels at skjule dette faktum for os og for sig selv ved sisyfoslignende at forsøge sig med endnu et ræsonnement, når det foregående er gået i nul. Men for at et ræsonnement kan opstå, ja hvis nedskrivningen (af teksten og af væren til nul) overhovedet skal kunne finde sted mellem nulpunkterne, må den have et materiale at brænde på og/eller en forskel at udligne. Således får vi efter "sovsekande med flaske" affødende forskellen "drøm versus bevidsthed " materialet „,vejret", forskel "udenfor/indenfor", dernæst dag/nat, lys/mørke, rolle/ingen rolle. Kulminationspunktet er den til alle tider primære opposition, binariteten at være eller ikke at være, så man kan ikke af nogen grund sige, at jég er hér., som senere varieres i „Jeg er ikke engang sikker på, om jeg er her."

Hvis Jeg ikke er, hvis alle forskelle er nedskrevet til nul, hvad er så - tilbage? Det er den tekst, som skriver at intet er. Tekstens forskel vil altid være der. Ikke kun som den velkendte oprindelige differeren i skriften men også som mere diskrete litterære forskels(fortsættende) effekter og strukturer indbefattende banaliteter som ords forestillingsindhold og narrativitet. 
I "Time out" er disse banaliter bemærkelsesværdigt fraværende, nogen har sørget for at fjerne dem. Der findes f.eks. ingen symbolforbindelser i teksten, hvis vi med symbolforbindelser mener den underjordiske forbindelse, der undertiden består mellem konkret og abstrakt, mellem rekvisit og betydning, som i fortolkningsøjemed kan bruges til at få delene til at passe sammen i helheden under formuleringen af tekstens metafysik. Derfor finder vi f.eks. ingen betydningsudvikling på sovsekanden med flasken, som på trods af et vist forestillingsindhold ikke forbinder sig med f.eks. afføringen, eftersom jeg'et kun skal bruge rekvisitten til at omdanne forskel til forskelsløshed; den refleksion, som sovsekanden afstedkommer, er ikke betinget af dennes potentielle symbolicitet. Det samme med radioen og fjernsynet (som ikke er der), deres tilstedeværelse gælder udelukkende nedskrivningen af væren til intet, hvorfor det ville være dårlig scenografi at indløse deres kommunikative symbolværdi, i stedet afskrives den. Af samme grund viger teksten også uden om det narrative, eftersom fortælling er lig med forskel, dvs., hvis topografien hed novelle og var organiseret som fortælling, ville jeg'et ikke længere kunne hævde ikke at være til. Derfor forekommer ingen handlingsudvikling, alt som hedder før, nu og efter er indeholdt i refleksionens permanente nu, hvoraf følger bl.a., at tyve timer er uden betydning for virkelighedsopfattelsen, , Jeg kalder det et stykke væren her mere eller mindre bevidst."

Alligevel genereres der et sted $i$ teksten en narrativ spænding, som forstyrrer jeg'ets væren/ikke-væren. Det drejer sig om kampen for uset at komme fra sommerhuset til havet. Kampen er narrativ i den forstand, at jeg'et tvinges til at sætte sin absolutte og ubetingede væren, som $i$ kraft af sin ubetingethed kan nedskrives til ikke-væren, på spil for at komme til havet, som er forskelsløshedens sted, al ikke-værens (læs: det udifferentieredes) korrelat, næsten i virkeligheden. Mellem huset og havet bryder verden ind, eller mere strategisk formuleret: den betingede væren mennesker, deres biler, mødets uberegnelige kausalitet og den kronologiske (aktive) tid - gør opmærksom på sig selv, netop som den ubetingede væren skulle til at kulminere. 
Dette kan vi kalde det litteræres list og ironi, som jeg' et i huset besejres af. Tekstens forførelsesakt går ud på at minimere den, i et ord, litterære effekt ved udelukkende at gøre brug af de mest trivielle virkemidler ud fra den idé, at en omfattende betydningsforladthed i det konkrete antyder stor sandhed i det abstrakte. Således kvalificerer sovsekandens trivialitet visdommen i ræsonnementet bevidsthed/ingen bevidsthed samtidig med, at kontrasten sovs/ånd korrelerer med ræsonnementets dialektik. Men hvis vi fjerner sovsekanden, viser det sig, at argumentet kun er en mystifikation af logikken, en efterlignen af et logisk udfoldet ræsonnement. Den overordnede nedskrivning af væren til intet bliver hermed postuleret, netop fordi sovsekanden er en æstetisk effekt. - og igen: bevægelsen fra sovsekande til ,ingen bevidsthed" fremtræder nok som en kausalistisk kæde af hvis'er og så'er, men konklusionen af ikke-væren følger ikke logisk men tilfældigt, æstetisk. Læg i den forbindelse især mærke til afsnittet om rolle, som ligner et ræsonnement men på det bestemteste blot er et stykke semantisk ornamentik.

Vi kan konstatere, at den tekst, der har som mål at udtale sig med sandhed om væren, må minimere brugen af gængse litterære virkemidler og blot forfølge en elementær kontrastiv strategi, eller også er det omvendt, at den tekst, der minimerer brugen af, i et ord, det litteræres æstetiske effekter, med nødvendighed må ende med at tale om væren. Men hvoraf følger det, at optagetheden af væren bliver til optagethed af ikke-væren? Det er tilsyneladende ikke en intenderet konsekvens fra forfatterens side og da slet ikke fra jeg' ets. Til gengæld er det en æstetisk konsekvens betinget af den erkendelse, litteratur altid skrives på og op imod: at alting opstår af intet og vender tilbage til intet. Digtet, novellen, romanen, topografien, teksten er altid først og fremmest legemliggørelsen af en intethedserfaring. Mellem bogens for- og bagside og mellem tekstens begyndelses- og slutbogstav opretholdes en momentan forglemmelse af intetheden før og efter skriften, en forglemmelse som imidlertid også kun eksisterer i kraft af intetheden. Således kan litteratur bl.a. beskrives som et forsøg på at skjule bevidstheden om intetheden og om sit eget 
endeligt, og vellykketheden af denne skjulen er grundlæggende det, der kvalificerer det litterære som sådant.

Tingenes betydningsløshed gør dem i sig selv betydningsfulde. Hvad angår sommerhuset og havet er betydningsfuldheden kalkuleret og intenderet, ikke som elementer i en symboludvikling, men derimod tilnærmelsesvist ikonografisk: havet eksisterer i højere grad som en intethedsforestilling end som vand. Sovsekanden stråler til gengæld på tværs af intentionen, idet den ikke bare er triviel, men oveni får den sin trivialitet beskrevet og bliver påfaldende neutral som en tilfældig materialisering af en geometrisk figur, den bliver m.a.o. litterær og får dermed væren i det omfang, litteratur altid er udfyldning af intethed med noget. Det er derfor, jeg'et i huset er så optaget af ikke at være, for ikke at være i en værende form, det er spørgsmålet, og samtidig det topografisten kæmper for, for retten til at bekendtgøre sit ophør og for retten til at være sin egen fortolkning.

Når "Time out" så holder fotografiet af væren frem, og vi ser, at det forestiller ikke-væren, er det ikke ensbetydende med at teksten har blotlagt litteraturens inderste, litteratur er altid skjulen af intetheden og "Time out" ikke en afsløring men højst en skjulen af, at litteraturen altid skjuler, for selv om fotografiet viser sig at være blankt, er det dog stadigvæk et fotografi. 


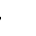

